\title{
「幸福な監視国家」の経済学 一産業政策・監視技術・文化対立一
}

\section{梶谷 懐}

\begin{abstract}
要旨 : 本論文では, COVID-19の流行と米中対立の顕在化を題材に, 現在の米国を中心としたリベ ラルな国際経済秩序が今後直面するであろう「危機」について，その具体的な性質について考察す る，考察にあたっては，「産業政策」「監視技術」「文化対立」というお互いに密接な関連性を持って いる三つのキーワードを軸に議論を進め,「危機」がもたらす価值観の対立をどう乗り越えるのかを 検討する.
\end{abstract}

[キーワード：中国経済，産業政策，監視社会，文化対立，COVID-19］

\section{1 はじめに}

本論文では，COVID-19と米中対立を軸に，現 在の米国を中心としたリベラルな国際経済秩序 が今後直面するであろう「危機」について，その 具体的な性質について考察する. 考察にあたって は, 以下の三つのキーワードを軸に議論を進めた い.

第 1 のキーワードは，「産業政策」である。近 年, 主流派経済学者の中で産業政策に対する関心 が高まっている.このような産業政策への積極的 評価への転換は，それまでの国家の介入を排した 自由競争を基盤とした, リベラルな国際経済秩序 に根本的な見直しを迫る可能性を内包している.

第 2 のキーワードは，「監視技術」である. COVID-19の感染に対して中国が見せた対応は， ビッグデータを利用したデジタル監視技術の有 効性を改めて認識させた。このような監視技術と その社会実装における国家と企業の共犯関係の 存在は，リベラルな国際経済秩序を支える「人権」 に代表される普遍的価值の共有を摇るがす重要 な論点の一つになるだろう.

第 3 のキーワードは,「文化対立」である. COVID-19の感染対策において，このような「文 化」の違いが感染抑制に大きく影響した可能性が 高い.さらに, 近年の文化進化と経済発展に関す
る研究成果によれば,このような文化の違いはい ったん形成されるとなかなか変化しないという 性質をもつ.このことは, COVID-19への対応で みられた監視技術の活用や行動制限に対する 人々の受容の違い, さらには「人権」のような普 遍的な価值をめぐる地域間の分断は, 今後も容易 には解消されず, むしろますます深まっていく可 能性が大きいことを意味する，そのことに多くの 人々が気付き始めたことは, 価值観の共有を前提 とするリベラルな国際経済秩序の維持にとって 一種の「危機」となりうるだろう。

以上のような, リベラルな国際経済秩序やそれ を支える価值観に関する「危機」をめぐる三つの 論点は，お互いに密接な関連性を持っている.だ からこそ，それらがもたらす「危機」をどのよう に乗り越えていくのか, が問われていると言えよ う.

\section{2 中国の「産業政策」をどう評価するか}

\section{1 経済学における産業政策の再評価}

岡崎哲二によれば，近年産業政策，すなわち 産業に対するミクロ的な介入政策に対する関心 が高まっている(岡崎, 2020)。 その例として岡 崎は, 欧州の学術誌 Journal of Industry, Competition and Tradeにおいて, これまでも産業政策の再評価 
を唱えてきたカール・アイギンガーとダニ・ロド リックという 2 名の研究者をゲストエディター として産業政策に関する特集号を組んだことを 挙げている.

同特集の中で, 近年の産業政策に対する経済学 者の関心が高まっている背景について,アイギン ガーとロドリックは, 発展途上国での産業構造変 化の要請, 先進国での長期的な労働市場悪化・金 融危機，大きな技術変化があると指摘している (Aiginger and Rodrik，2020)．注目すべき点は，彼 らが，上記の論点すべてに関わる事情として中国 の存在を挙げていることである.

そもそも，標準的な経済理論では，市場の失敗 がなければ投資の決定は民間に任せる方がよい と考えられていた。しかし，21世紀に入ってから の技術進歩の停滞と研究開発費の伸び悩みによ って，「知識のスピルオーバー」を根拠に多様な 産業政策が実施され，効果が検討されるようにな った．渡邊（2021）も指摘するように，「レフェリ 一役を務める政府が社会全体の利益を考慮する 枠組みが確保されている限り, 産業政策は有用と いう見方が強くなっている」のである.

「知識のスピルオーバー」を重視する産業政策 の代表的なものが, イノベーション促進政策であ る.ブルーム＝リーネン＝ウィリアムズは，「イ ノベーション（技術革新）振興政策のためのツー ルセット」と題した論文の中で，関連する実証研 究のサーベイに基づき, 研究開発補助金, 研究開 発費に関する税額控除，パテントボックス（特許 から生じる利益に関する優遇税制）など 9 つの政 策手段について，その効果に関するエビデンス，
政策の便益と費用の差を整理した（Bloom, Reenen, and Williams，2019). その結果，エビデン スの質やエビデンスによる結論性およびベネフ イットなどについて効果が高い政策ツールとし て研究開発の税額控除や熟練労働者の移民及び 貿易と競争などが挙げられることを示した。一方 パテントボックスやミッション志向の政策につ いてはその効果ははっきりせず, むしろ負の効果 が存在することを示している（表）.

このような状況に合わせ, 中国の産業政策につ いても, 従来の「幼稚産業保護論」的な保護関税 の特定の産業を保護・育成する政策としてではな く,「知識のスピルオーバー」を前提とした，よ り競争・イノベーション促進な産業政策として理 解する視点が必要となるだろう.

\section{2 中国の産業政策の効果に関する実証研究}

以下では, 近年に発表された中国の産業政策の 効果に関する実証研究を概観しておきたい. まず ベンチマーク的研究として挙げられるのが, アギ オンらの研究である（Aghion et al., 2015)。アギ オンらは, 1998年から2007年までの中国工業企業 データを使用し，同時期に中国政府によって実施 された産業政策を「競争力のあるセクターに補助 金を配分する政策」,「セクター内での競争を促進 させる政策」などに分類, それぞれが生産性に与 える影響を検証した，具体的には，産業の競争度 =ラーナー指数を測定し, 産業政策としては補助 金, 税制優遇, 融資, 関税の効果を総合的に分析 した.

分析の結果, セクター内の企業に分散して補助

表 イノベーション促進政策のツールキット

\begin{tabular}{|c|c|c|c|c|c|}
\hline & $\begin{array}{l}\text { エビデンス } \\
\text { の質 }\end{array}$ & $\begin{array}{c}\text { エビデンスに } \\
\text { よる結論性 }\end{array}$ & ベネフィット & 時間枠 & $\begin{array}{c}\text { 不平等への } \\
\text { 影響 }\end{array}$ \\
\hline 直接の研究開発補助 & 中 & 中 & 论柁 & 中期 & $\uparrow$ \\
\hline 研究開発の税額控除 & 高 & 高 & 武市方 & 短期 & $\uparrow \uparrow$ \\
\hline パテントボックス & 中 & 中 & 負の効果 & NA & $\uparrow \uparrow$ \\
\hline 熟練労働者の移民 & 高 & 高 & 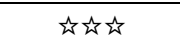 & 短〜中期 & $\downarrow$ \\
\hline 大学 : インセンティブ & 中 & 低 & 头 & 中期 & $\bar{\uparrow}$ \\
\hline 大学 : STEM 共有 & 中 & 中 & 论访 & 長期 & $\downarrow$ \\
\hline 貿易と競争 & 高 & 中 & 论地场 & 中期 & $\uparrow$ \\
\hline 知的財産権改革 & 中 & 低 & 不明 & 中期 & 不明 \\
\hline ミッション指向の政策 (ムーンショット) & 低 & 低 & 岤 & 中期 & 不明 \\
\hline
\end{tabular}

出所 : Bloom, Reenen, and Williams (2019) 
金を与え,「セクター内の競争を促進させる政策」 や, 新しくて生産性の高い企業を奨励する政策な ど, 産業政策が企業間の競争を促進するようにデ ザインされている場合に, 生産性引き上げ効果が 大きいことを示した. アギオンらによるファクト ファインディングは, 客観的な基準なしに特定の 企業を優遇する産業補助金を制裁の対象とする, WTO などの国際機関の基準にも合致している (渡邊，2021）.

中国の造船産業を対象としたバーウィックら の論文も特定産業を対象とした補助金の効率性 に疑問を投げかけている（Barwick, Kalouptsidi, and Zahur，2019）。同産業は2000年初頭には世界 シェア $10 \%$ に満たない存在だったものが，第 11 ・ 12 次 5 ケ年計画で生産・投資・参入に関する補助 金の供与によって世界シェア $40 \%$ にまで拡大し た。しかし，この補助金は非効率な生産能力の拡 大と過当競争を生じさせ,社会的には校正の損失 をもたらした，と彼らは結論付けている.

前節で言及したブルームらの研究で, 高いイノ ベーション促進効果を持つと評価された研究開 発に対する優遇税制の効果についてはチェンら (Chen, Liu, Suarez Serrato, and Xu，2020）が分析 を行っている. 2008年まで，中国では売上高に対 するR\&D投資が $5 \%$ 以上の企業に法人税限界税 率引き下げが行われていた. 2008年に行われた税 制改革では, 企業規模別に $3 \%, 4 \%, 6 \%$ の の闇值を設定，限界税率ではなく，平均税率の引 き下げをおこなうという変更が行われた.

チェンらは, この税制改革が企業のイノベーシ ヨンに与える影響について, 中国企業の法人税申 告書を対象とした国家税務総局のデータセット と中国工業企業データを組み合わせて分析を行 い, 税制改革により, 企業の報告された R\&D費は 闇値の周辺で有意な増加を示寸現象（=バンチン グ）が起きており，企業が経費を R\&Dとして再ラ ベリングしている可能性を検証した. 構造推定の 結果, チェンらは再ラベリングにより水増しされ た部分が政策により増加した R\&D の $24.2 \%$ 占 めていることを示した.また，政策シミュレーシ ヨンの結果から, 再ラベルリングのコストが低い 場合には，R\&D比の閾値に対応した補助金政策 はR\&Dの税額控除よりも効果的であること，た
だしその条件として R\&Dの波及効果が十分であ ることなどを指摘している.

\section{3 国有セクターの優遇と反腐敗運動}

政府による補助金が，特定産業だけでなく，国 有セクターなど, 特定の所有制を持つ企業を対象 としている場合には, 公正な競争を阻害する可能 性はより高くなる。この点に関し，チャンらは， 中国経営者雇用者調查 ${ }^{1}$ のデータを用いて，イノ ベーションを促進する補助金の配分と影響を検 証した (Cheng, Fan, Hoshi, and Hu，2019）。その 結果, 補助金は国有企業および政治資本のある企 業に優先的に配分されていることを明らかにし た。

彼らの分析によれば, 補助金を受けている企業 は, 特許出願数や特許取得数が多く, 新製品を導 入する可能性が高いが, 海外での特許出願数や特 許取得数は必ずしも多くない. また, 生産性が高 く, 利益が多く,市場シェアが高いわけでもない. このことは, 補助金の配分の非効率性を示唆する ものである.このような非効率な配分が行われる のは, 国有セクターを対象とした補助金で促進さ れるのが増分的なイノベーションであり，抜本的 なイノベーションを行うインセンティブは与え られないからだ，と著者らは指摘している。

ウェンとチャオは，第 1 節で取り上げた「中国 製造業2025（CM2025）」が企業の研究開発投資に 与える影響を2012年から2018年までの中国A株 上場企業 1,440 社のパネルデータを用いた DID (Difference in Difference) およびCEM (Coarsened Exact Matching) によって検証した（Wen and Zhao, 2020). 具体的には, CM2025の対象産業を事業内 容とする企業では, 政策介入後に研究開発投資が 大幅に増加していることが明らかになった. 彼ら によれば，CM2025の対象となった企業では政府 補助金や銀行融資が大幅に増加したものの, その 効果は国有企業の方が大きく, また政策によるイ ノベーション促進, TFP向上の効果は極めて小さ いことも明らかになった。これは，「中国製造 2025」が，特定の産業を優遇しようとするもので あり, 競争中立の原則に反するという批判を裏付 けるものであるともいえよう.

また, 中国では産業政策を含めた経済政策の実 
施全般が，政治の動向と不可分に結びついてい る. 習近平政権下の 2013 年に実施された反腐敗キ ヤンペーンと地方のイノベーションプログラム を担当する政府職員の交代という二つの外生的 イベントが補助金の生産性向上に与える効果を 分析したのが, ファンらの研究 (Fang, Lerner, Wu, and Zhang，2018）である. ファンらは上場企業を 分析対象とし，「腐敗度」の指標として年次報告 書に記載される「接待費・旅費」の額を用いて分 析を行った.

その結果, 研究開発補助金とイノベーションと の関連性は, 従来弱いものだったが, 反腐敗キャ ンペーン後には有意にプラスになることを示し た。このことは，污職防止のための努力や，企業 と役人の結びつきを断ち切るようなメカニズム が, 政府の研究開発補助金の配分効率を向上させ たことを示唆するものである，すなわち，污職防 止と企業の革新的能力向上の双方が政府の研究 開発補助金の配分に影響を与え, 競争促進的に働 いた可能性がある.

\section{4 「制度」の導入を通じた産業政策}

さて，以上みてきたように，現代の中国では特 定の産業やセクターをターゲットにした補助金 政策から, 研究開発促進のための補助金や税額控 除まで，様々な形態の産業政策が行われている. これらの産業政策は，基本的に，冒頭で紹介した ブルームらによる整理に見られるように, 競争を 促進するかどうかという評価軸をめぐり，主流派 の経済学の枠組みの中でその効率性を論じるこ とが可能なものだと言える，もう一つ，中国経済 を考える上で重要な産業政策は, 競争促進的な 「制度」の導入に関するものである。

猪俣（2020）は，法制度と産業政策との関係に ついて興味深い指摘を行っている. 寸なわち，伝 統的な国際貿易論では, モノやサービスの流れを 決めるのは各国の比較優位であり, またその比較 優位を決めるのは「労働, 資本 (人的資本を含む), 土地」といった生産要素の保有状況であるとされ ていた. 猪俣によれば, 第 4 次産業革命を背景に, この中から労働要素の重要性が大きく後退した という。 そして，今後各国の比較優位を考えるう えで新たに注目されるのが「制度」という要素で
ある.すなわち, 法制度の整った国ほど複雑な取 引関係を伴う製品の生産に比較優位があり, それ らを輸出する傾向にある（Nunn，2007; Nunn and Trefler, 2014)，というわけである.

そこで一つのカギとなるのが，リチャード・ボ ールドウィンが『世界経済 大いなる収斂 : ITが もたらす新次元のグローバリゼーション』（ボー ルドウィン, 2018年) で唱えた,「アンバンドリン グ」という概念である。まず，20世紀になって生 じたグローバル化によってモノと資本の移動が 自由になり, 生産と消費が切り離され, 先進国の 向上が途上国に移転するようになった。 これが第 一のアンバンドリングだ. 第二に, 情報通信技術 の発展によって, 生産プロセスの管理業務と生産 業務, さらにはそれらの内部の「タスク」も事細 かに国際分業することが可能になった. これが2 1 世紀になって本格化しつつある第二のアンバン ドリングである.

ブランコ・ミラノヴィッチは，第2のアンバン ドリングによって各国の「制度」の重要性が高ま ったことを指摘している（ミラノヴィッチ， 2021). 生産業務を本来の場所から移転させるた めには, 受け入れ国の制度や政治の質が重要にな るため，いかにそれを「中心」の制度に組み込む かが重要になる。例えば, 近年中国は知的財産権 保護の制度や, 破産制度など, 西側先進国の制度 をかなり巧みに中国的な文脈に合致させるよう に取り入れており，そのことが近年の活発なイノ ベーションの背景になっている.

ウォールストリート・ジャーナル紙の報道によ ると, 中国は2014年以降, 知的財産専門裁判所の 制度を整えており, 2019年にはIP 訴訟が48万 1000 件を超え，前年から50\%近く増えたという（「中 国の国家資本主義, ハイテク制覇の野望と両立せ ず」『ウォールストリート・ジャーナル日本語版, 』 2021年 1 月 4 日).さらに, 新たに導入された破 産裁判所も, 経営難企業の迅速な処理に役立って いる.リーとポンティセリによれば，中国では破 産裁判に要する期間が過去 10 年間の平均で約 1.6 年と, 米国の破産裁判より $60 \%$ 長いものの, 破産 専門の裁判所が手掛ける事例は通常の民事裁判 所よりも約 $35 \%$ 速く処理されるようになった（Li and Ponticelli, 2020) ${ }^{2)}$. 
このようなアンバンドリングの進行に伴って, 中国のような新興国による先進国の「制度」への キャッチアップの重要性が増していることは, 以 下の二つのことを意味していよう。一つは，グロ ーバル・バリューチェーンの一翼を担うような 「制度」やインフラを整備しさえすれば，先進国 がこれまで経験してきたステップを飛び越えて, リープ・フロッグ型の成長を遂げることが可能に なっていることである。もう一つは，そのような 新興国に意欲が可能な「制度」は，実際にはプラ ットフォーム企業が提供するシステムやノウハ ウ，すなわち，「無形資産」に多くを依存するも のになっている，という点である.

その一方で, 現在のグローバルに統合された資 本主義は, 中国のような新興国にとって, 先進国 のスタンダードに容易には収斂しないいわば深 層的な「制度」の存在もクローズアップしている。 それが文化的な差異を背景に持つ慣習や制度の 存在であり, その存在が中国の経済的な台頭に伴 う米国に代表される西側諸国との対立の深刻さ の背景となっている。この「制度」の二面性がも たら寸対立の深刻さそのものが，リベラルな経済 秩序にとっての「危機」の源泉にもなっている， ということが言えるだろう。

\section{3 監視技術と権威主義体制}

\section{1 Covid-19と監視技術}

筆者は，高口康太との共著（梶谷・高口，2019） の中で，ビッグデータを用いて市民に利便性と経 済的利益を与える一方でその情報を使って社会 の安定や治安の向上を図ろうとする中国の統治 体制を,パターナリズムと功利主義とが結びつい た「幸福な監視国家」であると評価した。その状 況は2020年のコロナ禍中国政府・社会のコロナ対 策の取り組みにおいて一層明確になった。

功利主義に従った意思決定は, 監視技術を駆使 した感染者の特定化・隔離にも効果を発揮してい る. その象徵が「健康コード」である。これはア リペイやウィーチャット・ペイなどのプラットフ オーム企業が提供するアプリから収集される，ス マートフォンの基地局情報を用いた個人の移動 記録, 公共交通機関や公共施設などを利用する際
にチェックイン方式で入手される移動情報, そし て個人の健康情報などを組み合わせることで，一 人ひとりの感染リスクを緑・黄・赤の3色で示す ものである.

健康コードが，コロナ禍の影響を受ける中で, 経済活動に大きな力を発揮したことは, ビッグデ ータを用いた実証研究からも明らかにされてい る.Xiao（2021）は, 杭州市における健康コードの ローンチのタイミングを利用したイベントスタ ディを行い, 健康コードの導入が工場稼働の指標 としての NO2 およびSO2 の排出量に有意な正の 影響を与えること, 同時に感染者数には有意な負 の影響を与えることを明らかにしている.

\section{2 「情報独裁」はどのように機能するか}

感染対策に限らず，こういったビッグデータを 用いて行われる民生向上のための施策は, 共産党 政権の支持基盤を盤石にするという効果を持つ. それは，このような「情報を通じた統治」が，現 代における権威主義国家の根幹をなすものとな っていることを意味している. 例えば，グリーヴ とトレースマンは, 独裁国家が行う政治的な殺人 の数が，1980年代以降，減少を続けていることに 注目したうえで，現代の独裁や権威主義が，あか らさまな暴力ではなく, 大衆に対寸る「情報操作」 を巧みに行うことを通じて, 政権への批判を封じ るようになっているとし, このような権威主義体 制のことを「情報独裁 (Information Autocrats)」と 名付けている（Guriev and Treisman, 2019).

「情報独裁」国家の重要な特徵の一つは, 議会 制や選挙などの民主主義的な制度を認めたうえ で, 選挙への介入や, メディア操作を通じて, 選 挙での勝利をおさめ, 政治的な正当性を勝ち取ろ うとする点である. 特に1990年代以降, 何らかの 選挙制度を伴う多党制度を採用する国家の比率 は大きく増加する傾向がある，一方で，1990年代 初頭から2012年までの間に, 非民主主義国で現職 に有利なメディアの偏向報道があったとされる 選挙の割合は, $35 \%$ から $58 \%$ に上昇したという3).

このような「情報独裁」国家は，インターネッ 卜を含むメディアにも介入し，できる限りあから さまではない形で巧妙な情報操作を行うように なっている. 中国に関しても, 胡錦涛政権の時代 
から，中国のネット検閲に関する複数の実証研究 が,ネットの検閲システムでは必ずしも政府に批 判的な投稿が削除されず, 放置される傾向にある ことが指摘されている。

例えば，2009年から2013年にかけて，中国で最 も著名なマイクロブログプラットフォームであ るSina Weibo（新浪微博）のブログ投稿の大規模 なデータセットを収集し，その分析を行ったチン らの研究（Qin, Stromberg, and Wu，2017）は，中 央政府がインターネットを行う際に, センシティ ブな内容であっても政権にとって重要な务威と なる可能性が低い投稿については削除を免れる ことを指摘している．同論文によれば，そのよう なセンシティブなコンテンツが放置されるのは, 政府が民衆の社会的な不満が顕在化する前にそ れに対処するためだという. 特に中央政府にとっ て，SNS の投稿を継続的に観測することは，人々 の地方政府の役人に対する評価をモニターする という役割を持っている.

他にもSNS などの検閲は選択的に行われてい たことを示す実証研究がある. ハーバード大学の 研究チームが2011年に行った研究では, 中国のあ らゆる掲示板やブログ, 微博等での投稿を, 高性 能コンピュータを用いて収集し，「検閲前」と「検 閲後」のデータを比べることで，検閲の実態を明 らかにした，興味深いのは，削除されやすいトピ ックの特定である分析の結果, 最も削除されやす い内容は「中国政府やその政策に対する批判」で はなく「集団での行動に繋がる内容」だったとい う点である（King, Pan, and Roberts，2013）.

もう一つ政府によって行われるのは, 政府に有 利な投稿の大量投稿である．キングらは，2014年 12月に, 江西省で2013年から2014年の間に宣伝部 の内部でやり取りされたメールの匿名によるリ 一ク情報を利用し，送受信履歴を解析し，いわゆ る「五毛党」と呼ばれる「やらせ」アカウントに よる投稿のメカニズムを明らかにした. 解析の結 果，同時期の江西省では4万件以上の投稿が「五 毛党」によって行われていたことが明らかになっ た。しかも，この投稿の99\%が政府職員によって 無給で行われていたという。投稿のほとんどは 「中国政府を称賛する」もので, 論争的な話題に 触れることはほとんどなく, センシティブな話題
からユーザーの関心を冕らすことが関心になっ ている.キングらは, 機械学習により微博アカウ ントを特定し, 中国全体のソーシャルメディア上 での「政府側による投稿量」を推計した。 その結 果， 1 年間で 4 億 4 千万件の投稿が為され，その ほとんど（6-8 割）がやはり「政府を称賛する」 内容だったことが明らかになった（King, Pan, and Roberts, 2017).

このような「物量作戦」的な世論操作が可能に なっている背景として, そもそもインターネット の情報から有意義なメッセージを受け取るには 高度なリテラシーが必要であり, 多くの民衆にと って共有されていない，ということがある。 スタ ンフォード大学と北京大学の研究者の共同研究 (Chen and Yang，2019）では，約1,800人の北京の 大学生を対象に, 自由に海外のサイトにアクセス できるツールを配布し，1年半にわたって継続的 な調査を行った，グループは（1）ツールなし， （2）ツールなし+ニューズレター，（3）ツール配 布，(4）ツール配布+ニューズレター，（5）既にツ ールを所持という5つのグループに分けられ $た^{4)}$.

各グループのアクセス量, 知識量や中国政府へ の態度等を 1 年半にわたって比較した結果, アク セスツールを受け取り，ニューズレターを送られ た学生の大部分はその他のグループと比較して 中国経済や中国政府の政策をより厳しく評価す るようになった。一方, ツールを受け取っただけ の学生は海外サイトへのアクセスを行わず, 事後 の認識にも変化はなかったという（Chen and Yang, 2019).

より巧妙な言論誘導の手法としては，例えば 「民主主義」や「人権」といったセンシティブな ワードをブロッキングするのではなく, その用語 を検索した時にヒットするワードの傾向に変更 を加えることで「検索による選択」を通じて世論 を誘導するものがある，ヤンとロバーツ（Yang and Roberts，2021）は，中国語版のWikipedia と， 百度百科という, 中国からのアクセスの条件が異 なる二つのオンライン事典サービスを用いて, セ ンシティブなワードに対する検索結果がそれぞ れの AIによってどう異なるかを分析した.

これらのオンライン事典サービスのアルゴリ 
ズムは，さまざまなテキストの特定の単語がどの ように使われているのかを学習する. 異なる単語 を物理的空間でつながったノードとして捉え，そ れぞれの単語が近ければ, その類似性も高いと判 断する。ヤンとロバーツによれば，中国語版 Wikipedia で訓練したアルゴリズムは，「民主主 義」を「安定」のような肯定的な言葉と結びつけ る傾向があった。これに対し，百度百科で訓練し たアルゴリズムで「民主主義」は，「混乱」のよう な単語に近いものとして捉えられていたという.

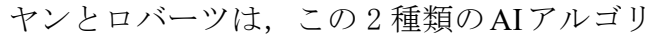
ズムを使って, ニュースの見出しから記事のニュ アンスを推測する言語プログラムを作成した。す ると，中国語版WikipediaのAIが「選挙」「自由」 「民主主義」といった単語を含む見出しに肯定的 なスコアを付けた一方で，百度百科の AI は「監 視」「社会統制」「中国共産党」などの単語がある とスコアが高くなる傾向があった．

このようなビッグデータの利用は, 民間企業が 政府行政の業務を委託されることにより，様々な ビッグデータの利用が可能になり，監視技術の開 発能力を高めるとともに, 行政の統治能力の向上 を図る，という「持ちつ持たれつ」の関係が存在 することを示すものでもある.

ベラジャ＝ヤン＝ユットマンの研究は, 顔認識 $\mathrm{AI}$ の開発を行っている中国企業を対象に，その イノベーション能力に関する指標と,地方行政か らの業務委託に関するデータをマッチングさせ ることで，AI企業が行政の仕事を受託すること でイノベーション能力が向上すること，そして行 政業務受託によるイノベーション能力の向上は, 県レベルで見た場合に，より入手可能なデータが 豊富な地域の業務を受託した際により大きくなる ことを示した（Beraja, Yang, and Yuchtman, 2020).

このことは，前節で論じた「イノベーション促 進的な産業政策」が，資源の効率的な配分をもた らすという意味で, 経済学的には評価されるもの であったとしても，それが必ずしもリベラルな価 值観に合致するものではない, ということを示唆 している. ビッグデータの利用を不可欠とする $\mathrm{AI}$ を用いた技術の開発は，収穫聥増的かつ予測 可能なイノベーションをもたらすものであり，も ともと産業政策と結びつきやすい.さらにはその
技術フロンティアは，一国もしくは民族，言語な どの規模の大きさに左右される, すなわち規模の 大きい国家ほど有利になるという側面も存在す る. 寸なわち, 中国のような，巨大な人口を抱え る権威主義国家が，AIを用いた監視技術の開発 を産官共同によって促進し, 権威主義的な統治を 強化していくことを，「競争をゆがめる」といっ た一般的な経済学のロジックだけで非難するこ とは困難だといってよいだろう．

\section{4 文化対立はなぜ表面化したのか}

\section{1 感染対策と文化的背景}

冒頭で述べたようにCOVID-19の感染対策に おいて，このような「文化」の違いが感染抑制に 大きく影響した可能性が高い。たとえば，昨年， 第 7 波の調査が公開された世界価值観調查の結 果を基に人々の価值観をマッピングしたイング ルハートーヴェルツェル図は, “confusion”すなわ ち儒教文化圈と分類された国々と, 英語圈の国々 および“Protestant-Europe”に分類された国々にお いて, 生存と自己表現のどちらを重要視するか, という価值観の違いを鮮明に示すものであった (梶谷2021).

この図において, 縦軸は伝統的な価值と世俗的 な価值の度合いを示し, 上に行くほど世俗的な価 值が強い、横軸は, 生存と自己表現のどちらを重 視するかを示しており, 右に行くほど表現の自由 を重視する度合いが高くなっている. 図の右上に 位置するプロテスタント・ヨーロッパに分類され ている国々が, 最も自由を志向する度合いが高 く,また世俗的な価值観が強い. それに対し, 中 央上に儒教文化圈としてひとまとまりにされて いる諸地域は, 世俗的な価值観は強い一方で, 欧 米諸国に比べより「自由」より「生存」を重視す る傾向がある. 日本の位置は, ちょうど両者の中 心に位置づけられている. また, この図では台湾 と中国が横軸でほとんど同じところに位置して いることも注目に值しょう。

またこれらの文化圈は, 例えば政府に対する信 頼性や無制限な権力への容認などの個々の論点 に関する回答においても, 際立った違いを見せて いる．例えば「政府を信頼するか」という質問に 
対する各国の回答の平均值では，中国が「大いに 信頼している」かかり信頼している」という2 2 の回答の合計が約 $80 \%$ を示すなど, 主要国の中で は群を抜いて高くなっている. それ以外の主要国 でも，この二つの回答の合計が $50 \%$ に達するのは 台湾や韓国など「儒教文化圈」に偏っている. COVID-19の感染対策においても,このような「文 化」の違いが感染抑制に大きく影響した可能性は 否定できないだろう。

もちろん，権威主義か民主主義か，といった形 式的な政治制度の問題とは異なり, 文化的な価値 観はそもそも単純な指標化になじみにくい.だか らこそ，この問題を論じるには指標化されたデー 夕を用いた数量分析だけに頼るのではなく, 異な る文化的背景を知るための十分な理解を払った うえで,丁寧な議論を行うことが重要なのだとい えよう。

\section{2 経済活動と文化的背景}

現代経済学では，ある社会における経済的ある いは政治的な「制度」と，歴史的・文化的背景と の関係についてどのように位置づけているのか. この点を確認するために, ダグラス・ノースの『制 度原論』における以下のような記述を参照してお こう（ノース，2015，p．150）。「自然環境の不確 実性に対処するために構築された制度や信念と， 人為的環境の不確実性に立ち向かうために構築 される制度や信念を対比することこそ,変化の過 程を理解する要諦である」.

ここでノースは，様々な制度を，日常生活にお ける様々な行為に構造を与え, 自然界の及び人為 的な「不確実性」を減少させるものだと述べてい る。ノースによれば，その不確実性は大きく二つ に分類される。一つは自然界，自然環境の不確実 性，もう一つは人為的な環境である。それらの異 なる不確実性に人間が対峙する際，「制度」に関 する異なる文化信念が生じることになる。（ノー ス, 2015).

近年, 主流派経済学の内部では, このような文 化信念に関する二分法に基づき，市場経済が発展 した社会の背景には, 西洋起源の個人主義的な文 化信念が存在し，そうではない社会には集団主義 的な文化がその背景にある，という命題を実証的
に検証する研究が盛んに見られるようになって いる，例えばジェラール・ロランは，史学および 考古学の研究に基づいて構築された古代〜現代 にわたる時期の様々な地域における「国家」の社 会経済状況に関するデータベースを用いて, 国家 主義システムと市場システムとの間の大きな相 違を特徴付けることを目的とする研究を行って いる ${ }^{5)}$.

同論文では，土地・奴隷の所有制度，法律制度 (財産法・契約法), 市場経済 (商業・貿易), 権力 の集中，都市・商人の役割，氏族関係，民族の多 様性などについて 1 〜 10のスコア付けを行い, 市 場活動（国内商業, 国際貿易）の発展度および法 体系，政治制度，社会制度に関する評価スコアの 間には密接な相関があることを示した. またロラ ンは，別の論文で，これらの古代の社会制度が， Hofstedeによる個人主義／集団主義の文化スコ アと深く結びついていることを示している (Roland, 2020).

\section{3 価值観に関するWIERDな偏り}

「文化」の重要性に注目しつつも，ロランらの 研究にみられるような, 西洋中心主義的な, 二項 対立的なとらえ方に疑問を呈しているのが，文化 を進化生物学的な枠組みで分析した研究で知ら れるジョセフ・ヘンリックらのグループによる一 連の研究である（Henrich, Heine, and Norenzayan, 2010).

彼らは, HofstedeやShalom Schwartzによる個人 主義／集団主義の分類を含め, 進化心理学や経済 学分析で行われている文化の累計指標が, 西欧で 教育を受け，工業化され，豊かで民主的な (WEIRD: Western, educated, industrialized, rich and democratic）社会のバイアスを強く受けたもので あることを主張している.これらの研究は, 人間 の行動や心理に関する多くの研究は, 誰もが最も 基本的な認知機能を共有していると仮定してお り，ある集団から得られた知見が全体に適用され ると考えている.しかし, そうではないことを示 寸証拠が増えているという。

ヘンリックらによれば, 視覚的知覚, 分析的推 論, 公正さ, 協力, 記憶, IQ の遺伝能力などさま ざまな領域において, 人間集団の間にかなりのば 
らつきがあることがわかっている。言い換えれ ば,これまでの人類学などで前提とされていたよ うな，豊かで教育水準の高い西欧社会の人々，特 にアメリカの大学生は, 人類全体からすれば偏っ たサンプルでしかない。にもかかわらず，先行研 究における被験者の $96 \%$ は，世界人口のわずか $12 \%$ 占める西欧先進国の人々であった.このよ うに，大多数の研究でWEIRDな被験者が使われ ているという事実は, 人間の心理や行動を理解す る上での大きな障害になっている, とヘンリック らは主張する ${ }^{6}$.

彼らは, 従来の文化的傾向を示す指標のサンプ ルが “WEIRD” に偏っていることから，それを是 正するために，生物学の固定化指標（FST）の導 出方法を参考にした独自の手法により，社会間の 心理的・文化的距離を測定した ${ }^{7}$.

さらに, 任意の集団を比較対象とした距離尺度 を作成し, 各国の文化的差異の研究を行った (Muthukrishna et al., 2020)。指標を作成する際に 参照された心理学上のデータは, WEIRD諸国, 特 に圧倒的に米国のサンプルが多いため，まず上記 の手法を用いて各国と米国との文化的距離を表 す指標を算出した. また彼らは, 比較対象として, 人口が最も多く, 経済規模が 2 番目に大きい国と して，各国の中国との文化的距離も算出してい る.

Muthukrishna et al. (2020) は，各国における米 国および中国との文化的な距離と, Hofstede (n.d.) やShalom Schwartzによる個人主義／集団 主義の分類を含む，一般的に用いられてきた心理 的・文化的差異の尺度との関係を見るため, 両者 の相関係数を測定した. その結果，米国との文化 的距離の方が, 中国との文化的距離よりも多くの 心理・文化的差異を予測していることが示され た. 寸なわち, これらの心理学的な指標は, 米国 に代表されるWEIRD社会を, ベンチマークとし て作成された可能性が高い, というわけである.

\section{4 歴史的制度と制度変化}

経済問題を考える際の歴史の重要性について, ネイサン・ナンは, 以下の二つの点を指摘してい る. 第一に, 経済に関し複数の均衡が存在する, いわゆるコーディネーション問題が存在する局
面では, 歴史的な変化がある一つの均衡から別の 均衡への恒久的な移動をもたら寸可能性がある こと, 第二に, 歴史的な出来事が, 国内の制度や 人々の行動規範, さらには文化など, 経済成長に 影響を及ぼすような決定要因を長期的に変化さ せていく可能性があることである (Nunn，2009).

一度形成された慣習は, たとえそれが望ましい 帰結をもたらさないことが自明であってもなか なか変更されることがない. ナンは, アフリカに おける奴隷貿易による原住民の収奪が，その後の アフリカ諸国の制度的発展を阻害してきたこと を2段階のゲーム理論を用いて示している (Nunn, 2007).

ナンによれば, 西洋列強による苛烈な植民地支 配は現地住民に対し，「生産性が高い活動を行え ば，それだけ多く収奪されるので，むしろ生産性 が低い活動を行った方が多くの効用が得られる」 という期待をもたらしたという。この期待によっ てもたらされる均衡は安定的なので, その後, 植 民地支配が終焉しても，社会において生産性の高 い活動を行うことが支配的となる均衡への移動 はなかなか行われなかった。 なぜなら, 生産性の 高い活動によって得られる利益を保護する制度 が形成されなかったために，そこに生活する個人 にとって生産性の低い活動から高い活動に自分 だけが移動することは, むしろ期待利得の低下を 意味するからだ.すなわち「より高い山に登るに は，今いる場所をいったん降りなければならな い」からである（Nunn，2020）。

ナンはまた, 一度形成された制度が変化しにく い理由として, 状況が変化してその制度が非効率 なものになったとしても, 政府は往々にして制度 に関する根本的な対処するのではなく, 新たな取 り決めを追加するなど断片的な方法で効率性の 問題を解決しようとしがちであることを指摘し ている. 結果的に, 社会システムは非常に複雑な 形で進化を遂げ（=「クラッジ」）, 本来のシンプ ルで効率なあり方からますます遠ざかってしま うことも多い（Nunn, 2020).

ただし，古代までさかのぼる「集団主義的な文 化的信念」と「個人主義的な文化信念」を対比さ せ，それらが異なる帰結をもたらす，という一部 の実証研究は, 決定論的な性格が非常に強いもの 
である．過去の文化的な背景が，現代の社会的な 制度を形作る構成要素となっていることは間違 いないにしても，それは文化決定論的に，集団主 義的なものが遺伝的に作用し，それですべてが決 まっているものとして理解すべきではない. 実質 的に，現代の社会制度が個人主義的であったり， 集団主義的であったりすることは間違いないに しても, それは何か特定の要素が決定していると いうよりは, ある社会における伝統や慣習も含め たさまざまな要素やそれに伴う社会構成員の相 互作用が，複雑に作用した結果としてとらえる心゙ きであろう。

\section{5 おわりに}

さて，これまで見てきたように，中国は，産業 政策により，技術面だけではなく，経済取引に関 する法制度の面などでも米国などに急速にキャ ッチアップしてきた。このような産業政策は，デ 一夕経済という規模の経済が働く分野での成長 を促した，その結果として，国民の行動をビッグ データを用いて制御する監視技術の進歩と社会 実装を可能にした。このような監視技術の進歩 が, COVID-19感染症の流行に対しても,「健康コ 一ド」の開発と普及を通じて，いち早く感染対策 と経済活動の両立を可能にした。しかし一方で, 文化的差異に起因寸る「価值観」における中国と 西側諸国の隔たりは埋まらず，そのことが米中の 深刻な対立をまねている，さらに，そのことに多 くの人々が気付き始めたことは, 価值観の共有を 前提とするリベラルな国際経済秩序の維持にと って一種の「危機」となりうるだろう。このよう な状況を乗り越えることは可能だろうか.

別稿で筆者は，このような文化的差異に起因す る対立を乗り越えるための一つのヒントを与え る思想として, プラグマティズムに注目すべきこ とを述べたが（梶谷，2020），ここでは，プラグ マティズムとも深い関連性をもつ思想として,へ 一ゲルの「承認論」に注目しておきたい。

ここでいう「承認」は，個人間の立場の違う人 たちの間における相互承認ということで捉える だけではなく, 個人がじういう社会の制度に対し てどのような態度をとるのか, 寸なわち個人がそ
れぞれの社会の制度を受け入れるのか, それとも 変化を求めるのかといったところにも関わって くる概念である, というのも, 承認は, 近代社会 の社会的諸制度がそれなしでは成立しないよう な原理であり，「個人は，自分自身や他者からの 承認要求に反応して, 制度を受容したり変えたり するようになる」(ヘルマン＝ピラート・ボルデ イレフ，2017，p. 90）からである.

なぜ,このような承認論が功利主義を乗り越え る上で重要になるのか. それは, 承認論が一見「動 物」的に見える人間の欲求や行動も, 実は人々の 相互承認によって形作られる社会的な「制度」に よって大きな影響を受けている，という立場に立 つからである。

$$
\text { ヘルマン＝ピラート・ボルディレフによれば, }
$$

人間の自然な欲望や欲求を実現するといった行 為も, 実は人々の相互承認およびそこから作り上 げられている社会的な制度の中で実現するもの にほかならない。すなわち,「自然な欲望は共同 の人倫的生活の複雑な制度的体系の中で媒介さ れ，それ自身を実現する（同書，p. 89)」のであ り，「われわれがルールに従うのは，インセンテ イブに反応するからではなく,むしろインセンテ イブを制度の一部として承認する」からである (同書，p. 94)。このようにして彼らは制度遵守 の根拠づけを, インセンティブとサンクションに のみ求める主流派経済学のアプローチ, 寸なわち 功利主義による制度の根拠づけを乗り超え, 後述 するような具体的な普遍性の追求と両立寸る形 で行ったのである。

上記のような承認論をベースにした制度のと らえ方は, 中国のような必ずしも我々と価值観を 共有するわけではない国家の台頭にどう向き合 っていくか, という課題についても, 大きな示唆 を与えるものであると，筆者は考えている.

(神戸大学)

注

1）分析のベースになった調査は, CEES が 2015,16 年に広東省・湖北省で実施したものである. 2016年には 1, 122 社, 9,103 人の従業員を対象に調查が行われたと いう.

2）ワン・ワン・リー（2014）は，中国の産業分類 
(CIC) 2 桁産業29業種77,000社を対象に, ヌン（Nunn, 2007）により提唱された契約集約度指標を用いて省ご との比較優位を推計している（Wang, Wang, and Li, 2014）。その結果ワンらは，世界銀行のリポートDoing Business in Chinaによる各省の投資環境の指標を用い て,より投資環境の整った地域に立地する企業は, 契約 集約型商品の生産に特化する傾向があることを見出し た

3） スウェーデンのヨーテボリ大学に本部のあるVDem 研究所が出している「民主主義レポート」の2021年 版では，世界各国の統治形態を自由民主主義（Liberal Democracy), 選挙民主主義（Electoral Democracy）, 選挙 権威主義 (Electoral Autocracy), 閉鎖的権威主義 (Closed Autocracy）の 4 つに分けているが，そのうち近年最も その比率が増加しているのが, 選挙権威主義だという (V-Dem institute, 2021).

4）（2）と（4）のグループに送られたニューズレター は政治的にセンシティブな海外ニュースへのリンクが 張られ，それらのニュースへのアクセスを促すものだ った.

5）このほかに, Gorodnichenko and Roland (2017) は, やはり Hofstedeによる個人主義／集団主義の文化ス コアを用いた分析を行い，個人主義的な文化がイノべ ーションの活発化に必要であることを証明している.

同じく Gorodnichenko and Roland (2021) は，同様の個人 主義／集団主義の区分が，現代の諸地域における民主 化の決定要因として重要であることを指摘している.

Greif and Tabellini (2017) は，ヨーロッパでは核家族が 形成されたのに対し，中国では共通の祖先にさかのぼ る父系の大家族「宗族（クラン）」が形成され，それが 相互扶助期の機能を担ったことが，ヨーロッパと中国 の個人主義をめぐる文化的な差異をもたらしたと指摘 している.

また，経済的な制度とその文化的背景さらには双方 の共進化に関する実証研究をサーベイした展望論文と してはAlesina and Giuliano（2015）がある。彼らは，ノ 一スらによる，文化や制度を「インフォーマルな制度」 として，法制度などのフォーマルな制度と同じ枠組み で論じようとすることは概念上の混乱をもたらすとし て, 批判的に論じている. Nunn (2020) も,「制度の進 化」という観点から長期的, 短期的な経済活動と「制度」 との間の双方向の影響性を分析した既存の研究につい て広範な文献サーベイを行っている。

6) 行動経済学, 神経経済学の専門家で, 中国研究の 業績も多いヘルマン =ピラートも, 中国と西洋社会の 差異が「個人主義対集団主義」という単純な二項対立で は分析できないことを強調する（Herrmann-Pillath, 2016).このような中国における社会的価值観に関する 洞察から，「個人主義」と「集団主義」に関する通説に も疑問が投げかけられる. 一般的に, 欧米の文化は個人 主義的であり，中国の文化は集団主義的であると理解 されてきた。しかし，著者によればこのような二項対立 的な理解は単純に過ぎる. 例えば, 個人主義／集団主義 の区分はその働く方向が社会の垂直方向か, 水平方向
化によって区別することができる. 中国は, 社会や組織 の階層性が強い, 寸なわち垂直方向の集団主義が強く, 水平的な社会関係においてはむしろ個人主義的傾向が 強いという。

7) Muthukrishna et al. (2020) では, 生物学の固定化 指標（FST）の導出方法を参考に作られた文化的固定化 指標（CFST）を用いて，各国間の文化的差異を測定す ることを試みている. 固定化指標 (FST) は, 各部分集 団の遺伝子型頻度が, 集団全体で無作為な交配が行わ れた場合の期待值と比べてどのように異なるかを測定 するものである.FST 2 つの集団の個体のゲノム上の 特定の遺伝子座（主な目の色の遺伝子のDNAの位置な ど) における対立遺伝子 (青い目や茶色の目の遺伝子変 異など）の集団間および集団内の分散の比率から導か れる. CFSTも, 遺伝的FST と同じ方法で計算されるが, ゲノムの代わりに, 文化的価值観に関する大規模な調 查を分析対象としてとして使用し, 質問を遺伝子座, 回 答を対立遺伝子として扱う。CFSTは，地域的，国民的， あるいは任意の文化的グループ (階級差など) を特定す るための解像度の高い手法であるという。

\section{参考文献}

猪俣哲史（2020）「国際貿易体制の行方（中）制度の似 た国同士で分業へ」『日本経済新聞』2020年 7 月 14 日.

岡崎哲二（2020）「21世紀の産業政策（中）枠組夕設計 競争促進重視を」『日本経済新聞』2020年 5 月 29 日。

梶谷懐（2020）「コロナウイルス感染症COVID-19 監 視社会」『サービソロジー』2020年 9 月 17 日.

梶谷懐（2021）「政治制度と『文化』：新型コロナウィ ルスへの対応をめぐって」『群像』第76巻, 第 11 号, pp. 202-209.

梶谷懐・高口康太（2019）『幸福な監視国家・中国』NHK 出版.

ノース, ダグラス (2015)『制度原論』（瀧澤弘和・中 林真幸訳）東洋経済新報社.

ヘルマン $=$ ピラート, カーステン・ボルディレフ, イヴ アン（2017）『現代経済学のヘーゲル的転回一社 会科学の制度的基礎』(岡本・㴰澤訳) NTT出版.

ボールドウィン, リチャード（2018）『世界経済 大い なる収斂：ITがもたらす新次元のグローバリゼ ーション』日本経済新聞出版.

ミラノヴィッチ, ブランコ（2021）『資本主義だけ残っ た』(西川美和訳) みすず書房.

渡邊真理子（2021）「補助金, 中立性・競争確保力ギ」 『日本経済新聞』2021年2月17日

Aghion, Philippe, Cai, Jing, Dewatripont, Mathias, Du, Luosha, Harrison, Ann and Patrick Legros (2015), Industrial Policy and Competition, American Economic Journal, Vol. 7, No. 4, pp. 1-32.

Aiginger, Karl and Dani Rodrik (2020), Rebirth of Industrial Policy and an Agenda for the Twenty-First Century, 
Journal of Industry, Competition and Trade, Vol. 20, pp. 189-207.

Alesina, Alberto and Paola Giuliano (2015), Culture and Institutions, Journal of Economic Literature, Vol. 53, No. 4, pp. 898-944.

Barwick, Panle Jia, Kalouptsidi, Myrto and Nahim Bin Zahur (2019), China's Industrial Policy: an Empirical Evaluation, NBER Working Paper, No. 26075.

Beraja,Martin, Yang, David Y. and Noam Yuchtman (2020), Data-intensive Innovation and the State: Evidence from AI Firms in China, NBER Working Paper, No. 27723.

Bloom, Nicholas, Reenen, John Van, and Heidi Williams (2019), A Toolkit of Policies to Promote Innovation, Journal of Economic Perspectives, Vol. 33, No. 3, pp. 163-184.

Chen, Zhao, Liu, Zhikuo, Suarez Serrato, J. Carlos and Daniel Y. Xu (2020), Notching R\&D Investment with Corporate Income Tax Cuts in China, NBER Working Paper, No. 24749.

Chen, Yuyu and David Y. Yang (2019), The Impact of Media Censorship: 1984 or Brave New World? American Economic Review, Vol. 109, No. 6, pp. 2294-2332.

Cheng, Hong, Fan, Hanbing, Hoshi, Takeo and Dezhuang Hu (2019), Do Innovation Subsidies Make Chinese Firms More Innovative? Evidence from the China Employer Employee Survey, NBER Working Paper, No. 25432.

Fang, Lily, Lerner, Josh, Wu, Chaopeng and Qi Zhang (2018), Corruption, Government Subsidies, and Innovation: Evidence from China, NBER Working Paper, No. 25098.

Gorodnichenko, Yuriy, and Gerard Roland, (2021), Culture, Institutions and Democratization, Public Choice, Vol. 187, pp. 165-195.

Gorodnichenko, Yuriy and Gerard Roland (2017), Culture, Institutions and the Wealth of Nations, Review of Economics and Statistics, Vol. 99, No. 3, pp. 402-416.

Greif, Avner and Guido Tabellini (2017), The clan and the corporation: Sustaining cooperation in China and Europe, Journal of Comparative Economics, Vol. 45, No. 1, pp. 1-35.

Guriev, Sergei and Daniel Treisman (2019), Informational Autocrats, The Journal of Economic Perspectives, Vol. 33, No. 4, pp. 100-127.

Herrmann-Pillath, Carsten (2016), China's Economic Culture: The Ritual Order of State and Market, Routledge.

Henrich, Joseph, Heine, Steven J. and Ara Norenzayan (2010), The weirdest people in the world? Behavioral and Brain Science, Vol. 33, No. 2-3, pp. 61-83.

King, Gary, Pan, Jennifer, and Margaret E. Roberts (2013), How Censorship in China Allows Government Criticism but Silences Collective Expression, The American Political Science Review, Vol. 107, No. 2, pp. 326-343.

King, Gary, Pan, Jennifer, and Margaret E. Roberts (2017), How the Chinese Government Fabricates Social Media Posts for Strategic Distraction, Not Engaged Argument, American Political Science Review, Vol. 111, No. 3, pp. 484-501.

Li, Bo and Jacopo Ponticelli (2020), Going Bankrupt in China, NBER Working Paper, No. 27501.

Muthukrishna, Michael, Bell, Adrian V., Henrich, Joseph, Curtin, Cameron M., Gedranovich, Alexander, McInerney, Jason and Braden Thue (2020), Beyond Western, Educated, Industrial, Rich, and Democratic (WEIRD) Psychology: Measuring and Mapping Scales of Cultural and Psychological Distance, Psychological Science, Vol. 31, No. 6, pp. 678-701.

Nunn, Nathan (2007), Relationship-specificity, incomplete contracts, and the pattern of trade, Quarterly Journal of Economics, Vol. 122, No. 2, pp. 569-600.

Nunn, Nathan and Daniel Trefler (2014), Domestic Institutions as a Source of Comparative Advantage, Chapter 5 in Handbook of International Economics, Vol. 4, pp. 263-315.

Nunn, Nathan (2020), History as Evolution, in Alberto Bisin and Giovanni Federico (eds.), Handbook of Historical Economics, Academic Press, pp. 41-91.

Qin, Bei, Stromberg, David and Yanhui Wu (2017), Why Does China Allow Freer Social Media? Protests versus Surveillance and Propaganda, Journal of Economic Perspectives, Vol. 31, No. 1, pp. 117-140.

Roland, Gerard. (2018), Comparative Economics in Historical Perspective: Presidential Address for the 2018 Association for Comparative Economic Studies Meetings, Comparative Economic Studies, Vol. 60, No. 4, pp. 475-501.

Roland, Gerard (2020), The deep historical roots of modern culture: A comparative perspective, Journal of Comparative Economics, Vol. 48, No. 3, pp. 483-508.

V-dem Institute (2021), Autocratization Turns Viral, DEMOCRACY REPORT 2021, University of Gothenburg.

Wang, Y., Wang, Y., Li, K., (2014), Judicial Quality, Contract Intensity and Firm Exports: Evidence from China, China Economic Review, Vol. 31, pp. 32-42.

Wen, Huwei and Zhao Zhao (2020), How does China's industrial policy affect firms' R\&D investment? Evidence from 'China Manufacturing 2025', Applied Economics, Vol. 53, No. 55, pp. 6333-6347.

Xiao, Kairong (2021), The Value of Big Data in a Pandemic, ? mimeo.

Yang, Eddie and Margaret E. Roberts (2021), Censorship of Online Encyclopedias: Implications for NLP Models, Fact '21: Proceedings of the 2021 ACM Conference on Fairness, Accountability, and Transparency, pp. 537-548. 